\title{
Effect of Fiber Surface Morphology on Water Sorption of Pre-treated Hemp Fiber Reinforced LLDPE Composites
}

\author{
Zane Zelca ${ }^{1}$, Silvija Kukle ${ }^{2}$, Janis Kajaks ${ }^{3}$, Edgars Kirilovs ${ }^{4},{ }^{1,2,4}$ Institute of Design Technologies, Riga Technical \\ University, ${ }^{3}$ Institute of Polymer Materials, Riga Technical University
}

\begin{abstract}
The chemical fiber pre-processing methods have been investigated, their influence on water absorption of linear low density polyethylene composites and fiber surface were evaluated by atomic force microscopy and water exposure experiments. All used fiber pre-processing methods decrease water sorption of composite. Untreated fiber composite with undamaged fiber surface more rapidly absorbs water.
\end{abstract}

Keywords - Composites, fiber surface, hemp fiber, Linear Low Density Polyethylene, pre-processing methods, water absorption.

\section{INTRODUCTION}

Hemp fiber properties can differ greatly depending on variety, agricultural complex applied, weather of growing season, type, grade, harvest quality, preprocessing methods, yield, etc. (1). Only natural fibers of high technical quality guarantee sufficient reproducibility of the mechanical characteristics of biocomposites (2). The investigation of influence of non-controllable (weather) and controllable factors (variety, agricultural complex, stem and fibers processing parameters) on fibers and their composite properties will allow to discuss and to evaluate anticipated unavoidable variation intervals of composite properties (3).

Natural fibers have a tendency to absorb water, but it is possible to decrease the amount of absorbed water thanks to chemical pre-processing of the fibers; it has a positive impact on the results in total composite exploitation.

A better understanding of the chemical composition and surface adhesive bonding of natural fiber is necessary in order to develop natural fiber-reinforced composites.(4)

The examination results of water absorption of LLDPE composites containing different types of hemp fibers showed that systems with $10 \mathrm{wt} \%$ untreated hemp fiber fillers absorbed almost the same water amount $(1.6 \%-1.8 \%)$ during $240 \mathrm{~h}$ exposure to water, but when the content of fibers increased up to $40 \mathrm{wt} \%$, the quantity of absorbed water differed more (5).

Water absorption deforms the surface of the composites by swelling and creating voids. The result of these deformations is lower strength and an increase in mass of the samples. Additionally, with increase of water absorption rates as high as $20 \mathrm{wt} \%$, the light weight advantage is often nullified (6).

The latest development, due to the environmental and ecological factors, biobased polymers from renewable resources have found increasing attention as potential alternatives to currently dominating petroleum based polymers
(7). Germany's nova-Institute study shows that current producers of bio-based polymers have estimated production capacity nearly 12 million tons by 2020 . With an expected total polymer production of about 400 million tons in 2020, the biobased share should increase from $1.5 \%$ in 2011 to $3 \%$ in 2020, meaning that bio-based production capacity will grow faster than overall production (8).

The most dynamic development is foreseen for drop-in biopolymers, which are chemically identical to their petrochemical counterparts but at least partially derived from biomass. This group is spearheaded by partly bio-based PET (Bio-PET) whose production capacity will reach about 5 million tons by the year 2020, using bioethanol from sugar cane. The second in this group are completely bio-based polyolefins like PE and PP, also based on bioethanol (8).

BioLLDPE from renewable raw materials behaves the same as PE based on petroleum. This means that bioPE cannot be composted or biodegraded. At the same time projections for year 2016 evidence that biodegradable bioplastics share will reach only $13.4 \%$ from anticipated bioplastics production volume $5779000 \mathrm{t} /$ per year, the rest $86.6 \%$ will refer to biobased/nonbiodegradable bioplastics (9) due to the fact that they can easily be recycled and can thus be included in the current waste separation process, and processed into new bioPE products using conventional technologies without requiring extra investments (10).

\section{MATERIALS AND METHODS}

Linear Low Density Polyethylene (LLDPE) grade LL 6201 was used as a polymer matrix.

Hemp fibers used in this study were obtained from hemp stems harvested from a trial plot at Agriculture Science Centre of Latgale in Vilani district, Latvia. Hemp fibers in growing process were cultivated with active nitrogen fertilizer (N30). The harvested hemp stems were left for dew retting on the field (4 weeks).

The content of hemp fibers (length up to $1 \mathrm{~mm}$ ) in composites was $30 \mathrm{wt} \%-50 \mathrm{wt} \%$ with pre-processing acetilation $11 \%$ solution $\left(4 \mathrm{~h} 20^{\circ} \mathrm{C}\right)$ and without pre-processing.

Composites were prepared by mixing of components on tworoll mill, then cooled, granulated and pressed in $1 \mathrm{~mm}$ thick sheets. Water exposure experiments (standard ASTM D 570-98) were carried out at room temperature $\left(+23^{\circ} \mathrm{C}\right)$.

Using atomic force microscopy fiber surface and composite adhesion was investigated. 


\section{RESULTS AND DISCUSSION}

Natural fibers absorb water from the air and direct contact from the environment. The surface of the fiber is a key condition to ensure good adhesion between the fiber and the matrix, chemical bonds may enhance physical links.

Water boiling process helps to separate fiber bundles into single fibers and to clean surface. Boiling does not significantly affect the fiber surface morphology, but after treatment fiber surface becomes smooth and clean from impurities (Fig. 1.).

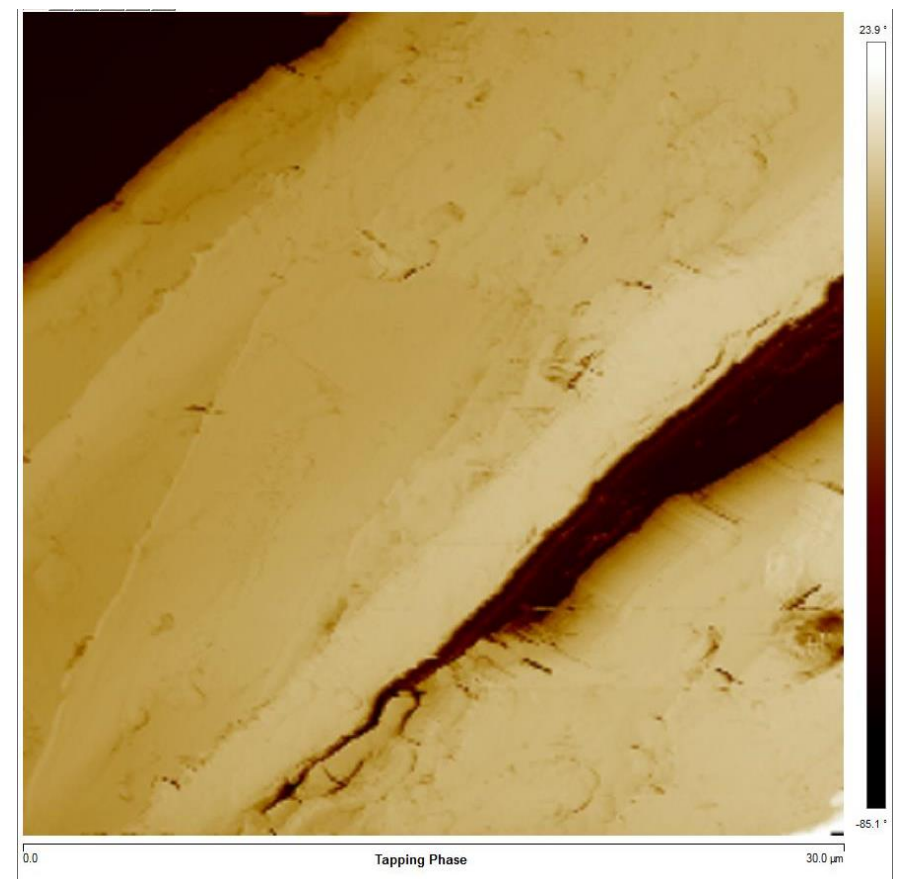

Fig. 1. AFM image of water boiled hemp fiber surface.

Sodium hydroxide treatment is commonly used for bleaching and cleaning the surface of plant fibers.

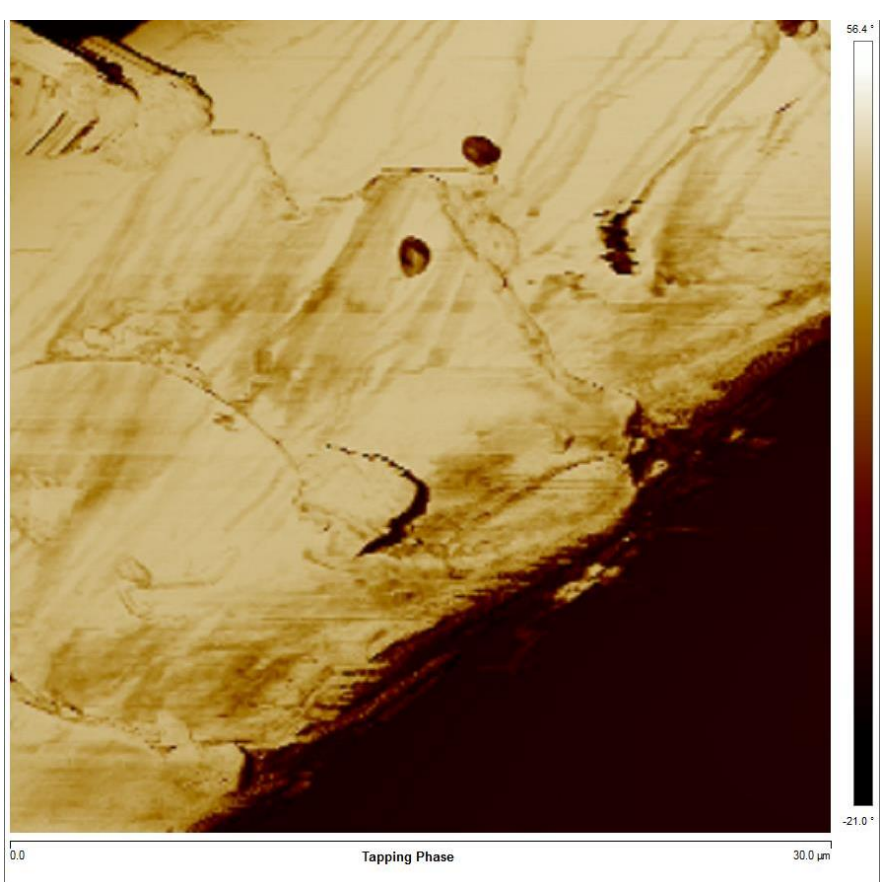

Fig. 2. AFM image of treated hemp fiber surface in $2 \% \mathrm{NaOH}$ concentration.
It also changes the fine structure of cellulose known as mercerization. After $2 \mathrm{wt} \%$ alkali solution treatment $\left(1 \mathrm{~h} 20^{\circ} \mathrm{C}\right)$ there were cracks seen on the fiber surface and some damage of outer layer of the fibers (Fig. 2.) that can result in decrease of fiber mechanical properties. It has been concluded from previous experiments that alkali pre-treatment and boiling are not transmitted to substantial improvements $(7.7 \%$ alkali and $7.6 \%$ boiled fiber $30 \mathrm{wt} \%$ hemp/LLDPE composite) water sorption after $336 \mathrm{~h}$.

Higher alkali solution concentration than $5 \%$ excess delignification of natural fiber occurs resulting in a weaker or damaged fiber (2).

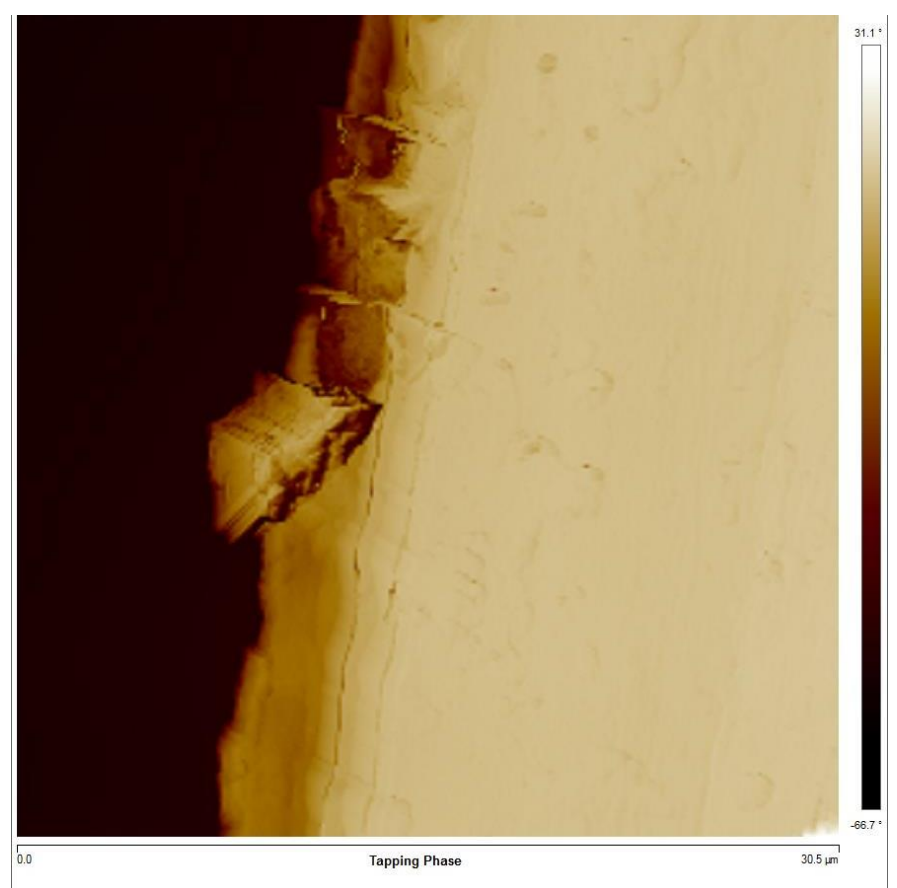

Fig. 3. AFM image of untreated hemp fiber surface.

Maleated coupling agents in contradistinction to other chemical treatments not only modify fiber surface but also modify matrix to ensure better interfacial bonding and improved mechanical properties of composites (13) - (15).

Untreated hemp fibers and coupling agent Licocene PE MA 4351 were filled into composite matrix by mixing components on two-roll mill.

As seen from the AFM micrography in Fig. 3 fiber surface is smooth, with some small pieces pulled out from the outer layer.

Acetic anhydride treatment effectively changes the free hydroxyl groups within the fiber into acetyl groups. When the free hydroxyl group is transformed to an acetyl group, the ability of the fiber to absorb water is greatly reduced.

From micrograph in Fig. 4 it can be seen that as a result of fiber pretreatment with $11 \mathrm{wt} \%$ acetic anhydride longitudinal cracks on fiber occurr and the structure of thick outer layer is changed. 


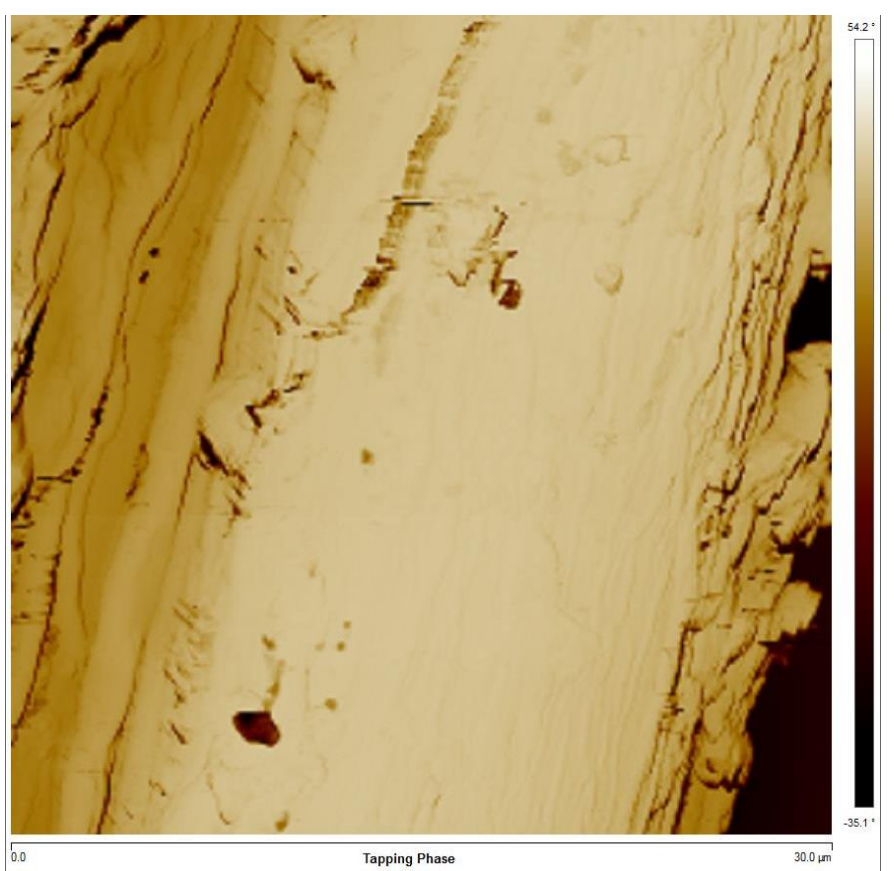

Fig. 4. AFM image of treated hemp fiber surface in $11 \%$ acetic anhydride concentration.

As expected, the untreated fiber composite with undamaged fiber surface more rapidly absorbs water $(8.3 \%$ after $336 \mathrm{~h}$ hemp/LLDPE $30 \mathrm{wt} \%)$ and with MAPE additive (7.78 \% after $336 \mathrm{~h}$ hemp/LLDPE $30 \mathrm{wt} \%$ ), but the water uptake is less than the amount of fibers that have been treated with acetic anhydride.

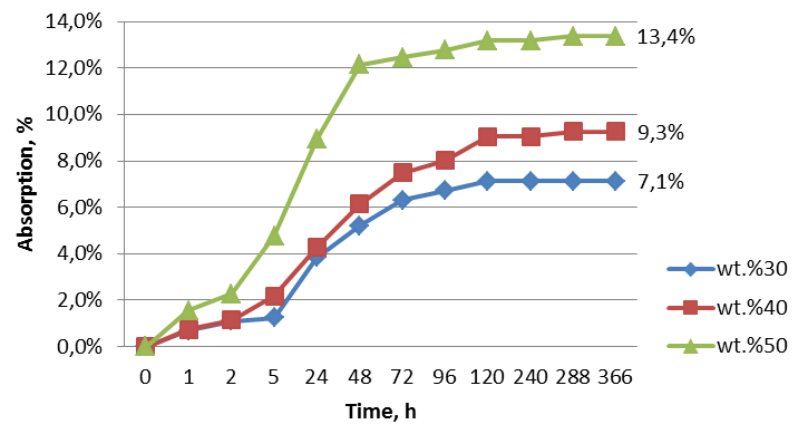

Fig. 5. Acetilated hemp fiber LLDPE composite water absorption.

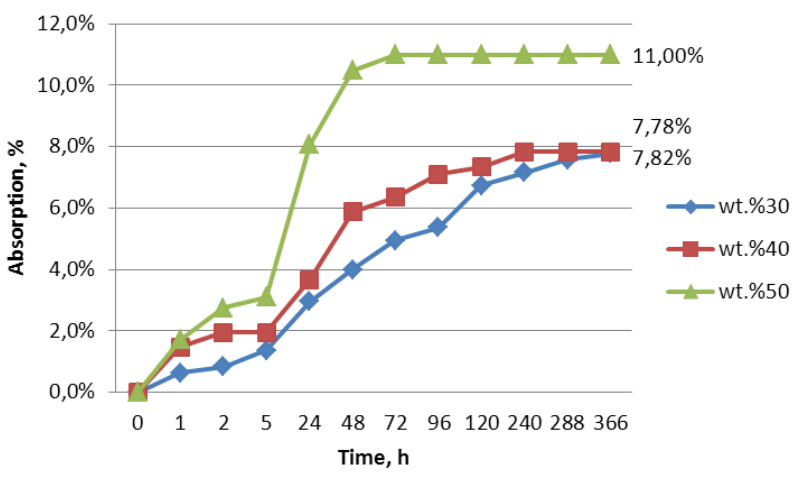

Fig. 6. Maleated hemp fiber LLDPE composite water absorption.

Acetylated fiber absorbs water more slowly, but equilibrium moisture content is higher.

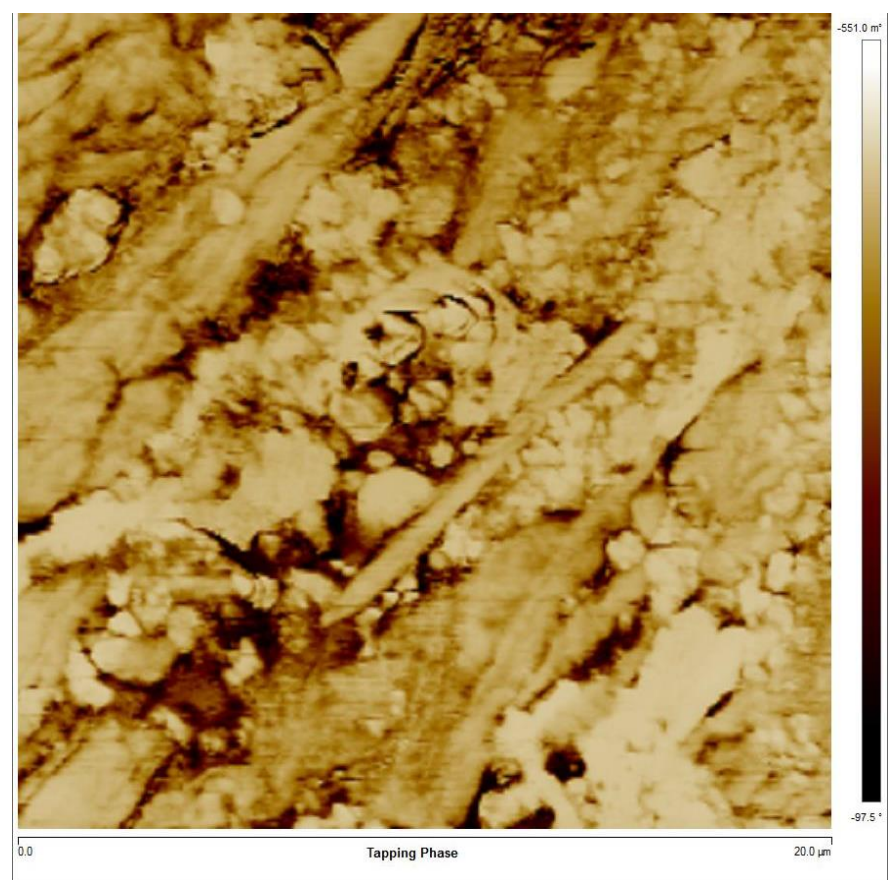

Fig. 7. Cross section of $30 \mathrm{wt} \%$ acetylated hemp fiber/ LLDPE composite.

Water sorption varies in a range $7.1 \%$ to $13.4 \%$ (acetilated fiber) and $7.9 \%$ to $7.78 \%$ (maleated fiber) and increases with fiber content improvement $30 \mathrm{wt} \%-50 \mathrm{wt} \%$. After 336-hour exposure to water the samples of all three composite variants established equilibrium moisture content (Fig. 5), (Fig. 6).

In case of low fiber content uneven loose packing of composite cross section with fibers and matrix is observed. (Fig. 7)

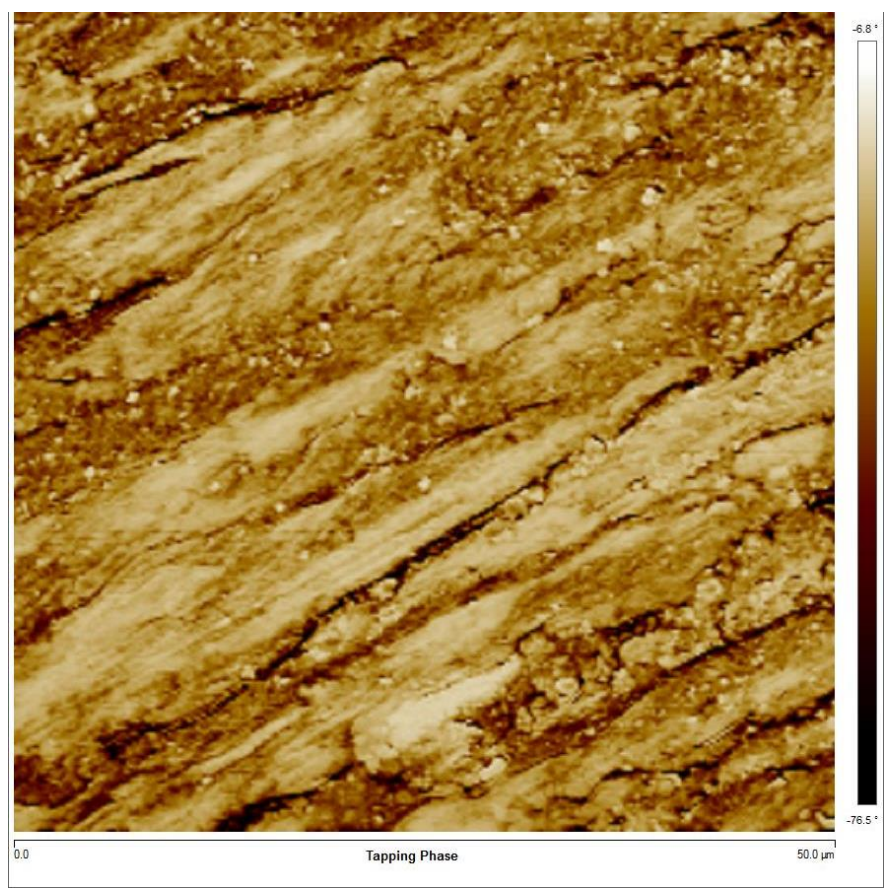

Fig. 8. Cross section of $50 \mathrm{wt} \%$ acetylated hemp fibers/ LLDPE composite.

In cross section of $50 \mathrm{wt} \%$ hemp fibers composite is seen compact packed with evenly spread compounds, fibers are tightly bound with matrix (Fig. 8) and in cross section of 
$30 \mathrm{wt} \%$ hemp fiber composite with MAPE fibers is tightly bound with matrix too (Fig.10).

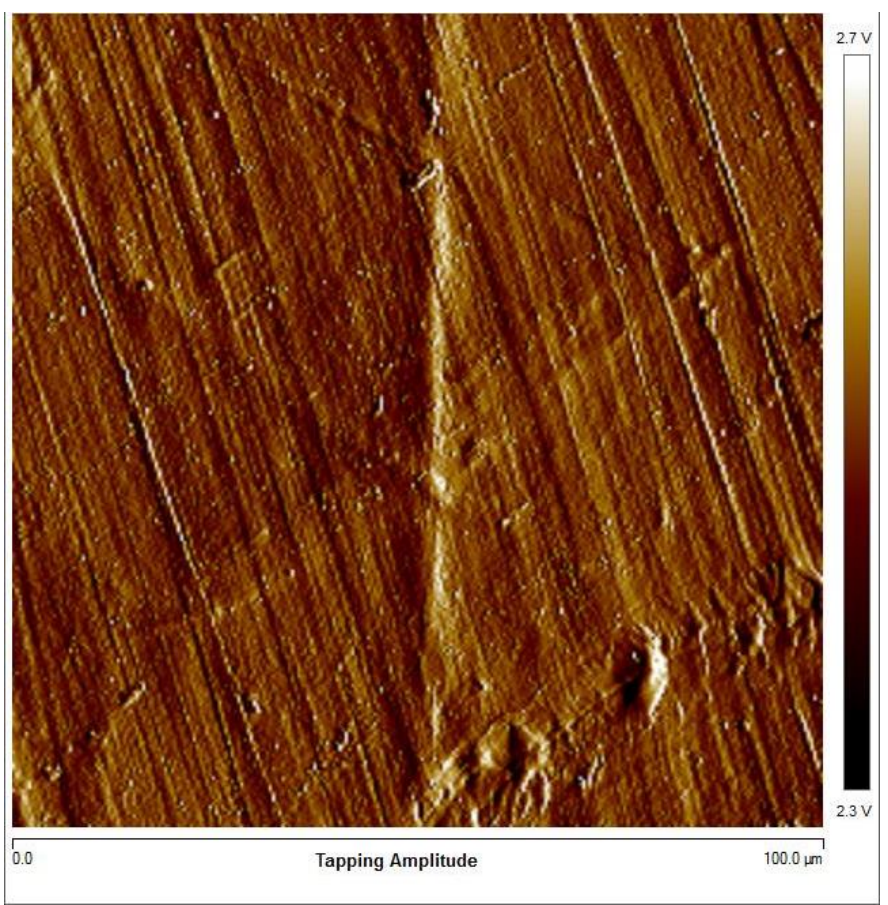

Fig. 9. Top section of $30 \mathrm{wt} \%$ acetylated hemp fiber/ LLDPE composite.

One can see that in the top section of $30 \mathrm{wt} \%$ hemp fiber composite the matrix completely covers the fibers and prevents the ingress of moisture in the fibers (Fig. 9).

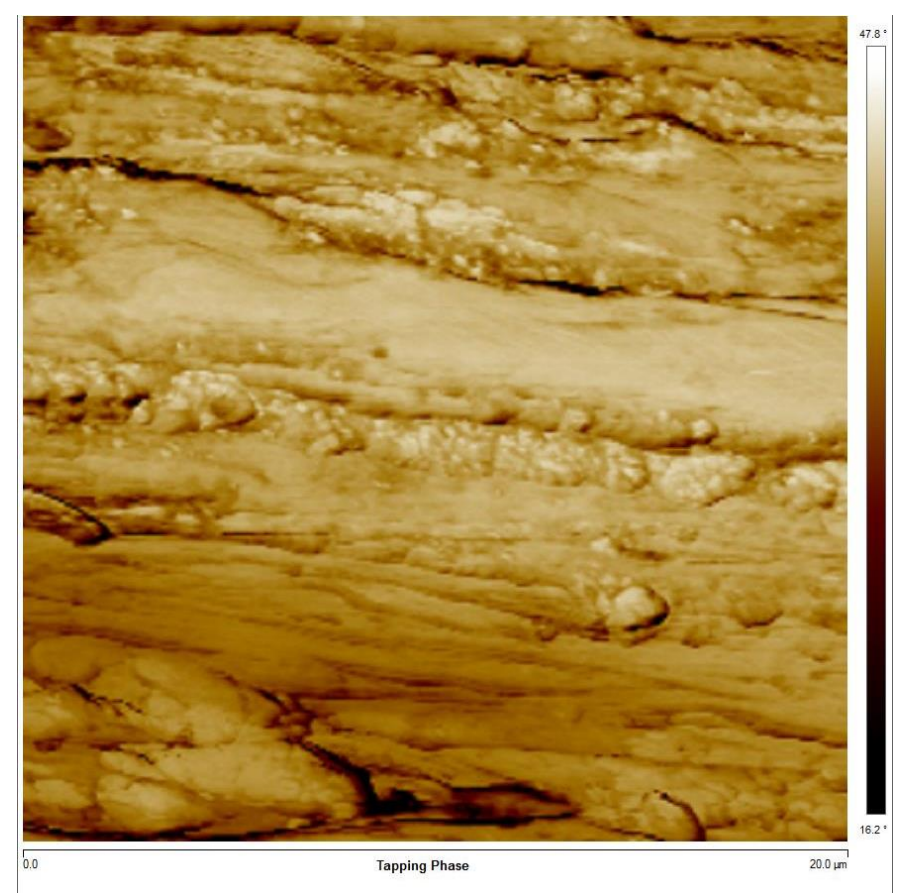

Fig. 10. Cross section of $30 \mathrm{wt} \%$ untreated hemp fiber / LLDPE composite with MAPE.

The tabs on the sample top surface consist of polyethylene locked fibers and scratches after pressing.

\section{CONCLUSION}

Chemical treatment can increase the interface adhesion between the fiber and matrix, and decrease the water absorption of the fibers. All used fiber pre-processing methods decrease water sorption of composite - with MAPE additive by $0.5 \%$, with alkali solution by $0.6 \%$, with boiled fiber by $0.8 \%$ and with acetic anhydride by $1.2 \%$, for composites with fiber content $30 \mathrm{wt} \%$. Water sorption after $336 \mathrm{~h}$ varies in a range $7.1 \%$ to $13.4 \%$ and increases substantially with the increase of the fiber content from $30 \mathrm{wt} \%$ up to $50 \mathrm{wt} \%$.

\section{REFERENCES}

1. Kukle, S., Stramkale, V., Kalnina, D., Solizenko, R. Comparision of Hemp Fiber Properties. In: the 6th Int. Textile, Clothing \& Design Conf. Dubrovnik, Croatia, 2012, pp. 76-80. ISSN 1847-7275.

2. Pickering, K., Properties and performance of natural-fiber composites. Boca Raton: CRC Press LL, 2008.

3. Harmsen, P., Hackmann, M. Green building blocks for biobased plastics. Biofuels, Bioproducts and Biorefining. vol. 8, Issue 3, 2014. pp. 306-324. http://doi.org/2x8

4. Xue, L., Tabil, L. G. Chemical Treatments of Natural Fiber for Use in Natural Fiber-Reinforced Composites. A Review, J. Polym. Environ., 2007, vol. 15, Issue 1, pp. 25-33. http://doi.org/cgdfvj

5. Nestore, O., Kajaks, J., Vancovica, I., Reihmane, S. Physical - mechanical properties of composites based on linear low density polyethylene and natural fibre textile waste. Mechanics of composite materials. 2012, vol. 48 , no. 6 , pp. 897-910.

6. Kalita, D., Himadri, D. Recent Development of Fiber Reinforced Composite Materials. CSIR - North East Institute of Science and Technology. Assam, India, 2014. ISBN-13: 978-1118773512.

7. Production Capacities for Bio-based Polymers in Europe - Status Quo and Trends towards 2020 [online]. [viewed 20.10.2014.] Available from: http://www.bio-based.eu/market_study/pressrelease

8. Mülhaupt, R. Green Polymer Chemistry and Bio-based Plastics: Dreams and Reality [online]. Macromolecular Chemistry and Physics. 2013, vol. 214, Issue 2, pp. 159-174 [viewed 29.10.2014.] Available from: http://www.braskem.com/site.aspx/green-products-USA

9. Braskem. Green Products 2011 [online]. [viewed 27.10.2014.] Available from: http://www.braskem.com/site.aspx/chemistry-sustainable-USA Mwaikambo, L. Y., Ansell, M. P. Chemical Modification of Hemp, Sisal, Jute, and Kapok Fibers by Alkalization. J. Appl. Pol. Sc., vol. 84, Issue 12, pp. 2222-2234, 2002, Wiley Periodicals, Inc. http://doi.org/cf88q8

10. Gassan, J,. Bledzki A. K. The influence of fiber-surface treatment on the mechanical properties of jute-polypropylene composites. Compos Pt. A: Appl Sci Manuf. 1997, vol. 28, pp. 1001-1005.

11. van den Oever, M., Peijs, T. Continuous-glass-fibre-reinforced polypropylene composites II. Influence of maleic-anhydride modified polypropylene on fatigue behavior. Compos. Part A: Appl. Sci. Manuf., vol. 29, Issue 3, 227-239, 1998. http://doi.org/bczt6p

12. Joseph, P. V., Joseph, K., Thomas, S., Pillai, C. K. S., Prasad, V. S., Groeninckx, G., Sarkissova, M. The thermal and crystallisation studies of short sisal fibre reinforced polypropylene composites. Composites Part A: Appl. Sci. Manuf. vol. 34, Issue 3, pp. 253-266, 2003. http://doi.org/bh59z3

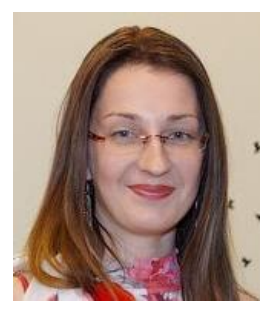

Zane Zelca received the Master degree in Technology and Design from the Institute of Design Technology of RTU in 2014. She is a Doctoral student with the Institute of Design Technology, RTU, and Head of Laboratory of the Department of Design and Material Technology, Institute of Design Technology, Faculty of Materials Science and Applied Chemistry, RTU. She is an Assistant Researcher with the Institute of Design Technology of Riga Technical University. Address: Institute of Design Technologies, Riga Technical University, Azenes Str. 18, Riga, LV-1048, Latvia.

E-mail: zane.zelca@rtu.lv 


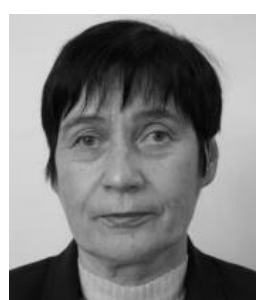

Silvija Kukle is a Professor with the Institute of Design Technologies of RTU. She received the qualification of Engineer Technologist in 1965. In 1977, she received the degree of Candidate of Technical Sciences. In 1991, she received the Doctoral degree of Engineering Science. She obtained the Dr.habil. sc. ing. degree in 1993 and has been a Professor since 1994. She is Head of the Department of Technology and Design.

Address: Institute of Design Technologies, Riga Technical University, Azenes Str. 18, Riga, LV-1048, Latvia.

E-mail: skukle@latnet.lv

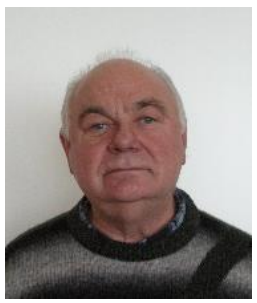

Janis Kajaks received the Doctoral degree in Engineering Science in 1978 from Riga Polytechnical Institute. He received the qualification of Engineer Technologist in Plastic Processing Technology in 1969. From 1969 - 1984, he worked as a Lecturer at the Department of Polymer Processing Technology of Riga Polytechnical Institute. Since 2007, he has been an Associate Professor with the Institute of Polymer Materials and the Department of Technology of Polymer Materials of RTU

Address: Faculty of Material Science and Applied Chemistry, Riga Technical University, Azenes Str. 14, Riga, LV-1048, Latvia.

E-mail: kajaks@ktf.rtu.lv

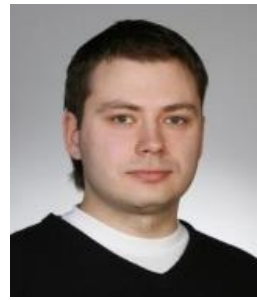

Edgars Kirilovs, received the $D r$. sc. ing. degree in 2013 from Riga Technical University. He currently is a Lecturer with Riga Technical University. His main fields of research are: the use of innovative boards in the production of wooden products and wood product design adjustment to the options of modern technologies.

Address: Institute of Design Technologies, Riga Technical University, Azenes Str. 18, Riga, LV-1048, Latvia.

E-mail: edgars.kirilovs@rtu.lv

Zane Zelča, Silvija Kukle, Jānis Kajaks, Edgars Kirilovs. Priekšapstrādātu šḳiedru virsmas morfoloğijas ietekme uz kaṇepju šḳiedru un lineāra zema blīvuma polietilēna kompozītu ūdens absorbciju

Rakstā sniegts ieskats par dabisku šḳiedru kompozītu ūdens absorbciju, šḳiedru priekšapstrādes tehnoloǵiju ietekmi uz biopolimēru ražošanas attīstību. Pētījumā raksturoti šḳiedru priekšapstrādes veidi, to ietekme uz škiedru virsmas morfologiiju, izmantojot ar atomspēku mikroskopu iegūtus kaṇepju škiedru virsmas uzṇēmumus, salīdzinātas vārītas, acetilētas, neapstrādātas un merserizētas šḳiedru virsmas. No kaṇepju šḳiedrām un lineāra zema blīvuma polietilēna izgatavotie kompozīti testēti atbilstoši standartam ASTMD 570-98. Grafikos attēlota ūdens absorbcijas kinētika kompozītiem ar kaņepju škiedru saturu robežās no 30 mas\% līdz 50 mas\%. Eksperimentā iegūtie dati ḷauj salīdzināt kompozītus ar acetilētām škiedrām un škiedrām, kam pievienots MAPE. Ūdens absorbcijas rādītāji atkarībā no šḳiedru procentuālā satura variē robežās no 7,1 \% līdz 13,4 \%. Neviens no kompozītiem ūdeni vairs neuzsūc pēc 336 h. Kompozītu virsmas un šḳērsgriezuma uzṇểmumi liecina par labu adhēziju starp acetilētām kaṇepju škiedrām un matricu.

Зане Зелча, Силвия Кукле, Янис Каякс, Едгарс Кириловс. Воздействие морфологии предварительно обработанной поверхности волокна конопли и ЛПЭНП композитного водопоглощения

В статье приводится обзор водопоглащения, влияния технологии предварительной обработки природных волокон на свойства волокнистых композитов и развитие производства биополимера. В результате анализа микрографий, полученных атомно-силовым микроскопом, характеризуется влияние предварительной обработки волокон и эффектов на морфологию поверхности волокна, сравниваются термически обработанные, ацетилированные, необработанные и мерсеризованные поверхности волокон.

Композиты, изготовленные из волокон конопли и линейного полиэтилена низкой плотности, были испытаны в соответствии со стандартом ASTMD 570-98. На графиках проиллюстрирована кинетика поглощения воды композитов, содержащих от 30 мас\% до 50 мас\% волокон. Экспериментальные данные позволяют сравнивать композиты с ацетилированным волокном и с добавкой малейнизованного полиэтилена. В зависимости от процентного содержания волокон водопоглощение композитов варьирует в диапазоне от 7,1 \% до 13,4 \% Все композиты достигает точки равновесия водопоглощения nосле 336 ч. Поверхности и поперечные сечения композитов свидетельствуют о хорошей адгезии между ацетилированными волокнами конопли и матрицы. 